\title{
Language diversity in education: evolving from multilingual education to functional multilingual learning
}

Sven Sierens and Piet Van Avermaet

\begin{abstract}
This chapter argues that multilingual education is not the only way of responding to language diversity at school; indeed, the large number of home languages present in many schools means that it is impossible to implement traditional modes of bi- and multilingual education. We begin by distinguishing between the multilingualism of educational elites, which involves languages that enjoy a high degree of cultural prestige, and the multilingualism of children from immigrant homes, whose languages are often felt to have no educational value. We then consider the arguments advanced in favour of monolingual and multilingual educational models. Proponents of the monolingual model believe that children from immigrant backgrounds should be immersed in the language of schooling; home languages have no role to play at school because they are seen as obstacles to effective acquisition of the majority language. Proponents of bilingual models, on the other hand, argue that education partly in the pupil's home language provides a more effective basis for learning the language of schooling than immersion, enhances pupils' self-esteem, and helps to preserve immigrant languages. A review of empirical research shows that there is no knock-down argument in favour of one particular model of language education; clearly, no single model can possibly suit all contexts. We propose that there are three strategies for responding to linguistic diversity at school: a constructive language policy; raising language awareness; and facilitating functional multilingual learning. This last is conceptualised as an alternative to the binary opposition between monolingual and multilingual education: a new pedagogical approach that exploits children's plurilingual repertoires as didactic capital for learning.
\end{abstract}




\section{Introduction}

The multilingual context of the school and classroom is a hot topic; it occupies the mind of schools, teachers and society as a whole. A lot of schools are struggling with their multilingual character. Specialists emphasise the importance of multilingualism: it's an added value for all who aim to work and function in Belgium and Europe. Children are encouraged to learn French, English, German, Spanish and Italian and, if possible, to use these new languages at home, with friends and on holidays. On the other hand we see that the multilingualism of immigrant minority children, adolescents and their parents is often considered to be an obstacle to success at school. In Flanders parents are sometimes encouraged to abandon their own language in their conversations with their children and give priority to Dutch. In some cases children are discouraged or forbidden to speak any language other than Dutch while at school. In most cases these measures are not inspired by a negative attitude towards the native language of immigrant minority children. Schools are truly concerned about the learning opportunities available to these children. Nevertheless we do have to wonder what will happen when they hear that learning foreign languages is important for their future but their own 'foreign' language presents an obstacle or handicap for that same future. This chapter explores this aspect of diversity in the educational system, arguing that there is no reason to limit language diversity at school to the organisation of multilingual education (section 1). After all, this implies a quite unconventional structural change in the school programme and it is not the most relevant solution for all contexts and schools, given the fact that many schools in Flanders have become hyper diverse, in the sense that often 10 or more different languages are spoken at school. To deal with linguistic diversity within an educational environment one can use three strategies: a constructive language policy (section 2), linguistic sensitisation (section 3) and functional multilingual learning (section 4). 


\section{Monolingual versus multilingual education}

Linguistic diversity or multilingualism is a specific aspect of diversity within the educational programme. Discussion about multilingualism long focussed on language teaching: what type of language education fits pupils from underprivileged immigrant backgrounds the best, monolingual or multilingual? Schools choosing a multilingual approach can use more than one language of instruction and administration and teach their regular curriculum subjects in different languages.

In Flanders for ideological reasons, this remains a controversial topic when it comes to children and adolescents from ethnic minorities.. However, instead of addressing this discussion from an ideological perspective, we will focus in this section on the available scientific research on the topic since both supporters and opponents seem to interpret the relevant research to suit their own purposes. Generally speaking, both in Flanders and internationally, the debates on this issue are divided into two camps: monolingual (language immersion or submersion) versus bilingual (or multilingual) education. Bilingual education has always been a controversial subject, especially in Flanders, with only a minority of people prepared to defend it. Even immigrant parents and students have different opinions on the subject (e.g., Agirdag, 2010). A clear example is the case of proposition 227 in California in 1998. In a referendum on bilingual education many of the Hispanic parents voted in favour of the English-only initiative instead of the maintenance of bilingual education. Monolingual education is the mainstream model in the Flemish educational system and is generally supported by society at large. Since the Flemish educational system is based on just one official language/language of schooling, most people find it self-evident and normal that students should speak only Dutch when at school (except of course for foreign language courses). The opinion of many teachers is in line with the monolingual norm of a Flemish federal state in which the administrative elite aims at linguistic homogeneity (Dutch) in all 
domains of public life (education, administration, the law) (Blommaert \& Van Avermaet, 2008; Verlot, 2001). Most Flemish people also rely on their common sense and assume that the best way to learn a new language is to immerse yourself in it.

Supporters of monolingual education are convinced that it is best to immerse non-native children in the Dutch language as soon and as often as possible. Within this perspective the home language of these children has no place in the classroom or elsewhere in school and is not included in the curriculum. Supporters of language immersion programmes do not oppose the principle of multilingual education as such (see below). They are however convinced that the use in school of the home languages of children from underprivileged immigrant backgrounds will obstruct the development of proficiency in the language of schooling, a thorough knowledge of which is a precondition for educational success and integration in the labour market and in society generally.

A lot of Flemish schools consciously combine a language immersion model with a monolingual, Dutch-only language policy and ban non-native minority languages entirely. Sometimes these principles find their way into the school regulations (for example: "no language other than Dutch allowed in the school yard") and students are punished for breaking the rules. Besides the argument of 'integration' there is also the aspect of 'time': whenever children use their home language, they steal away time they could use to practise Dutch and as such slow down the development of the second language (Van den Branden \& Verhelst, 2008). From this point of view, some argue that multilingual education, or even the spontaneous use of the home language, leads to 'being zerolingual' and in the end to complete educational failure (Blommaert \& Van Avermaet, 2008).

On the other side of the argument, the supporters of bilingual (or multilingual) education are convinced that children benefit from an education in their own language - in addition to or in combination with education in the majority language of schooling, which for 
them is a second language. They argue that education in the mother tongue provides a more effective basis for learning the language of schooling than total immersion. Secondly, learning their native language at school would improve the wellbeing of children from migrant backgrounds by supporting positive identity construction, which is known to have a positive influence on school results. Thirdly, teaching non-native languages helps these languages to survive over time. In this perspective providing educational support for minority immigrant languages is an objective of a government policy that acknowledges multilingual education as a positive feature of a multicultural society. The native languages of non-native students are valued for what they are, independent languages, and not simply used as a useful crutch to support the learning of Dutch or improve students' wellbeing and involvement.

The project 'Onderwijs in Eigen Taal en Cultuur' (OETC - Education in Minority Language and Culture) in the 1980s and 1990s experimented with the use of immigrant languages in Flemish schools. In most cases immigrant students were taken out of the classroom and were taught in their own language for a few hours a week (Turkish, Italian, Spanish, Arabic ...). They also followed additional courses in the history and culture of their home country. Initially the purpose was to prepare these children for a return to their home country. When immigrants took up their permanent residence in Belgium the initial objective of the OETC project was replaced by the motives and objectives mentioned in the preceding paragraph. The OETC project was quite successful in the 1980s when about 50 Flemish schools included it in their educational programme. Subsequently the project went downhill. The main reason was a lack of official Flemish financial and organisational support (Delrue et $a l .$, 2006). In May 2011, the Flemish Minister of Education took the decision to stop subsidising the bicultural trilingual education model of Foyer, an NGO that ran six elementary schools in Brussels, in spite of its good international reputation and several positive evaluations carried out in the course of its thirty-year existence (e.g., Byram \& 
Leman, 1990). In 2008, the city of Ghent started a long-term experimental project in four elementary schools, 'Thuistaal in Onderwijs' (Home Language in Education), in which inter alia Turkish children are taught to read and write Turkish when they enter primary school before making the transition to Dutch literacy instruction (Stad Gent, 2007). Today this is the only type of (transitional) bilingual education available to immigrant students in Flanders.

\subsection{Research on multilingual education: a critical reflection}

The United States and Canada has extensive and long-term experience with bilingual and multilingual education for children from immigrant and minority groups, especially Spanish/English programmes for the Spanish-speaking population of the USA. This has generated extensive research on the possibilities and effects of the different language education models. When it comes to the development of theories on the subject, the USA has a lead over its European and Flemish counterparts as well. Supporters of bilingual education can fall back upon the insights of the Canadian educational psychologist Jim Cummins (1979, 2000). In the seventies he formulated a theory to explain the effectiveness of bilingual education. Based on an interdependency theory of language acquisition, he states that the acquisition of educational skills such as counting, reading and writing, in a language other than the mother tongue, is facilitated by a high level of achievement in the first language. For example, the easiest way to learn to read and write is to learn it in the language you know best, your first language (or better, the formal version of your first language). The Canadian psychologist Wallace Lambert introduced two new concepts, 'additive' and 'subtractive' bilingualism. Additive bilingualism refers to the acquisition of a second language without losing the skills acquired in the first language, mostly because society appreciates and

acknowledges both languages as being equal. Subtractive bilingualism refers to a situation in which the acquisition of a second language, often enjoying a higher status, threatens the first 
language and gradually replaces it. Subtractive bilingualism often occurs when society does not value the first language and feels that it should disappear or be put aside for the benefit of the second language (Lambert, 1974). This is the case for a lot of immigrants to western Europe.

In the USA the contradiction between monolingual and bilingual education grew into a political conflict between the 'English-only' movement and the supporters of 'bilingual education' (Padilla, 1991), which meant that the discussion found itself in an impasse (Köbben, 2003). The available research offered no clear direction, despite the fact that since the early 1970s hundreds of American studies had been published on the subject. However, in recent years new best-evidence syntheses (August \& Shanahan, 2006; Genesee et al., 2006) and meta-analyses (Francis et al., 2006; Rolstad et al., 2005) seem to have tipped the balance slightly in favour of strong types of bilingual education programmes. These have modest but consistent positive effects on English language and literacy learning. On the other hand, a recent study by Slavin and colleagues (2011) reports the results of a five-year evaluation study that compared the reading and speaking performance of Spanish-dominant children randomly assigned to transitional bilingual education (TBE) or structured English immersion (SIE) at the beginning of kindergarten. The findings suggest that children learn to read in English equally well in TBE and SIE.

Hence, it is clear that the discussion about which models work best is far from settled. The American scientific research continues to suffer from problems. First, a lot of studies have methodological shortcomings (they are insufficiently comparative, measure only shortterm effects, fail to include pre-testing, etc.). After the necessary sifting little research remains from which we can draw well-founded conclusions. High-quality and long-term studies about, for example, transitional bilingual education are scarce, very difficult to set up, and often 
based on secondary data (e.g., Thomas \& Collier, 2002). Ideally, research needs to take account of the following five considerations.

First, studies should commence the day children enter kindergarten and last until they switch to education given exclusively in the second language. This implies that studies should start with sufficient participants to ensure that despite the inevitable drop-out they are able to draw valid and reliable conclusions (Slavin \& Cheung, 2005).

Secondly, there is the problem of comparing chalk and cheese: there are a great many different models of both monolingual and bilingual education (Archibald et al., 2004; García, 2009). Comparing them demands a careful and fair analysis which is sometimes hard to find in the different studies. For example, some studies claim that a certain model of language education works very well, but when you take a closer look, you notice that the alternative models used for comparison are not sufficiently underpinned, i.e. they are not always built on firm foundations. Different studies show evidence of a positive effect of bilingual education, but when it turns out that these studies used as a control group children learning English according to the 'sink-or-swim' method (having to make it on their own without any didactic support), it is no wonder that bilingual education ends up with better scores.

Thirdly, there seems to be a theoretical problem. Some experimental studies show a positive effect of bilingual education on different variables (second language acquisition, psycho-social variables, educational success) but they do not find evidence for Cummins's transfer hypothesis (see above), which thus remains contestable. One aspect is however worth remembering: when it comes to achieving a successful transfer from the first to the second language, minimal models, in which only a few hours of the weekly teaching package are devoted to the native language, fall short.

Fourthly, scientific research focussed for too long on the question of the best model for all circumstances and students: either the monolingual model or the bilingual model, not a 
combination of the two. This 'either-or' approach has its roots in the desire of policymakers and those active in the educational sector to find an easy way out, a 'catch-all' model. The research however suggests that an easy answer or a 'catch-all' model simply does not exist because most researchers start from the wrong basic assumption (Köbben, 2003).

And fifthly, research that is premised on programme types rarely gets close to what actually happens in the classroom (Leung, 2005).

It is starting to become clear that all models - monolingual, bilingual and multilingual have their advantages, and that the choice of a model should depend on the context in which it will be used and the category of students it will address. At least as important to effectively guarantee the quality of an educational model is the quality of the learning environment and the way the pre-conditions are met - both the educational and organisational ones (for example: clearly described objectives, a structured curriculum, guaranteed funding, competent and committed bilingual teachers, sound teaching materials, intensive cooperation within the school team) (August \& Shanahan, 2006).

Discussion of monolingual and bilingual education is further complicated by the fact that the educational quality of schools and the educational success of pupils depend on other factors besides language education. There are several variables in play but unfortunately supporters of both educational models sometimes seem to forget this important detail in the heat of their discussions. Language is an important key to success but by no means the only one. However, a lot more research is needed before we can formulate clear and specific answers to new basic assumptions and questions about context and quality. In particular we need research in which researchers and practitioners join forces to develop scientifically supported practical models.

This detour around American research on educational models and theories brings us back to European and Flemish reality. The North American context is quite different from the 
European and Flemish one. Hence, caution is advisable when considering these North American results and conclusions from a European perspective. Is there a lesson to be learned from the research on language teaching done in Flanders and neighbouring countries?

Unfortunately the answer is no. For a start, there are too few projects that focus on multilingual education. Secondly, western European studies suffer from the same methodological shortcomings as their American counterparts. The conclusion of recent reviews is quite clear: too few studies provide exclusive evidence for the positive impact of bilingual education on western European migrants with a low socio-economic status (Söhn, 2005). An as yet unpublished meta-analysis carried out by Gabrijela Reljić at the University of Luxembourg indicates that bilingual programmes that include the child's first language are superior to monolingual programmes in securing educational success, but this is based on only seven studies selected from over a hundred carried out in Europe to date.

On the other hand, studies providing conclusive evidence of the negative impact of bilingual education are scarce. This implies that in general bilingual education does not impair the development of the second language. This conclusion gives policy makers and those in charge of the educational sector an additional reason to play the card of the monolingual immersion model (which has already happened in the Netherlands). Scientific research does not support the theory that language immersion for non-native students is the best solution in all circumstances, but sometimes political choices are made based on ideology and emotion rather than on scientific research. The problem in Flanders boils down to the implementation of multilingual models. To be able to prove the effectiveness of multilingual models through research, and show that they sometimes work better than the language immersion model, the government should facilitate the implementation of these multilingual models. However, the government refuses to invest further in multilingual education for immigrants, arguing that research studies have failed to show positive effects when using this model. It is important to 
note that there is barely any research available on the topic and multilingual education (as offered in the OETC project) has never received proper support. In short, multilingual education has never had a chance to prove itself.

\subsection{Research on multilingual education: the pros}

In any case, the current is running against the supporters of multilingual education. To turn the tide they will have to come up with more convincing scientific arguments than they do today. The first argument they use refers to the positive effects of bilingualism. There is quite consistent evidence for cognitive benefits such as increased attentional control, working memory, metalinguistic awareness, and abstract and symbolic representational skills even for low-SES groups (Adesope et al., 2010).

A second argument refers to the more general positive results of bilingual education (Baker, 2006; Hamers \& Blanc, 2000). At first sight, there is no room for debate here. Bilingual education is organised all over the world and is often successful. Much-quoted examples are the French immersion programmes for English-speaking students in Quebec (Canada) and the Catalan immersion programmes for Spanish-speaking students in Catalonia (Spain). There is little or no dispute about the positive effects of these programmes (Cummins, 2000; Huguet et al., 2000; Lazaruk, 2007). But in almost all cases the programmes involve students who come from high-status groups and are learning a second language in a context of additive bilingualism. For example, English-speaking students who follow a French immersion programme in schools in Quebec are not asked to discard their native language. And in any case, English is far from being a threatened minority language. On the other hand, with a professional career in mind French-speaking students have everything to gain by learning English, the majority language in Canada. International and European private schools in and around Brussels also offer multilingual educational 
programmes and they encounter little opposition from those who advocate language immersion programmes for underprivileged students. These multilingual programmes target elite students who wish to learn high-prestige languages and who will enjoy greatly increased opportunities to build a successful international career, thanks to their multilingualism.

A third and last argument refers to the strong focus on successful models of multilingual education for immigrant minority groups that are implemented in totally different social, cultural or immigrant contexts. As we suggested earlier, using tried and tested American models can be quite treacherous. Different analyses show that one of the most powerful models of bilingual education is 'two-way bilingual education', a model in which children with different native languages learn each other's language through interaction in the classroom (for example, Spanish-speaking children learn English and English-speaking children learn Spanish). It remains an open question whether this should work in Flemish classes. When organising a few hours per week of native language education for immigrant children already causes a big stir in the media, one may wonder what kind of reaction this 'two-way bilingual education' model would evoke. The Netherlands and Germany have more experience with bilingual education programmes for immigrant minorities than Flanders. A synthesis of the available scientific research in both countries shows mixed results (Driessen, 2005; Gogolin, 2005; Söhn, 2005) and is not very promising for the supporters of bilingual education.

In conclusion, the scientific doubts about the added value of multilingual education in the context of subtractive bilingualism remain. Unfortunately this is the precise context in which a lot of non-native students in western Europe, and Flanders, find themselves (Hamers $\&$ Blanc, 2000). It is clear that policy makers and other actors in the educational sector have little difficulty with multilingual education in which students learn languages with a high level of prestige. This point of view derives from the fact that the educational systems of other 
European countries succeed in delivering competent multilingual students better than they used to. The international reputation of Flanders for multilingualism is at stake and the Flemish educational system threatens to lose its pole position (Delrue et al., 2006).

Knowledge of the French language is fading as well, mainly because the federalisation of the Belgian state has psychologically estranged the Flemish and French parts of the country and young people are starting to think in more international terms, preferring to learn English, Spanish and Chinese rather than French. Today multilingual education serves as a means to improve the quality of foreign language education for indigenous children preparing for a future career in a worldwide knowledge economy.

Since 2004 Flemish elementary schools have been allowed to incorporate 'language initiation' into their curriculum. This is an accessible and exploratory form of second language teaching in which children, and toddlers, are initiated in the French language in a playful way (through games, songs, chat sessions with a doll). Although language initiation can be used with any language, French gets priority. CLIL (Content and Language Integrated Learning) was introduced in nine Flemish secondary schools and offered students the possibility of following courses such as history and geography in a foreign language (French, English or German). A lot of European countries are experimenting with the CLIL approach, including the Walloon provinces in Belgium (for an overview, see Mettewie \& Housen, 2012). The present Flemish Minister of Education favours a more widespread implementation of CLIL but intends to confine it to secondary schools, on the ground that its introduction in elementary schools might endanger the Dutch language skills of too many non-native language speakers. 


\section{Dealing with linguistic diversity at school, strategy 1: a constructive language}

\section{policy}

It is quite clear that in the present Flemish educational system it is difficult to advocate an intensive multilingual educational programme in schools with a lot of non-native, underprivileged children, certainly not as a valid alternative to the dominant Dutch language immersion model. The Flemish educational system holds a double (contradictory?) attitude towards multilingual education: it is considered an enrichment for privileged native children but a threat to the Dutch language skills and educational success of non-native, underprivileged children.

This however does not mean that the home languages of these children are of no use at all. In cities such as Antwerp, Ghent, Genk, Mechelen and Brussels the percentage of children with home languages other than Dutch is on the rise; hence, language diversity is a given fact (for Brussels, see Verlot et al., 2003). Their home language is one of the assets these children bring to school with them, and it is part of the multilingual repertoire the school can exploit rather than ignore or ban. After all, there are many ways of dealing with linguistic diversity, from banning home languages (or completely ignoring them) at one extreme to organising multilingual education at the other.

A first and easy option is to introduce a constructive and open language policy that includes all the languages students and their parents speak. This policy is based on separating the language immersion principle from a monolingual school regime. As mentioned before, a lot of schools link their Dutch language immersion programme to a 'Dutch only' school policy. They not only adopt the language immersion principle in class but use it as a criterion for judging all behaviour at school (in the corridors, the playground and the refectory).

Children speaking different languages need to seize every opportunity to exercise their Dutch, especially because the opportunities to do so outside school are scarce. Experts on second 
language acquisition however have their doubts about the argument that 'the greater the exposure, the better'. After all, it seems non-native children master everyday Dutch quite easily (Van den Branden \& Verhelst, 2008). Research by Jürgen Jaspers (2005) into the spontaneous speech of Moroccan adolescents in secondary schools in Antwerp shows that they fully mastered different varieties of informal Dutch. The most important obstacle for immigrant-origin students seems to be academic language, which is a lot more abstract and decontextualised than everyday Dutch (Laevers et al., 2004). In secondary technical and vocational schools, non-native students have no problems with the spoken language (Dutch) but struggle to write it correctly. Apparently their 'language problem' has more to do with literacy than with the language in general. To improve the school language and literacy of these non-native students we need years of concentrated teaching effort (Van den Branden \& Verhelst, 2008). The language of schooling is best taught and practised in class. Outside the classroom, students use informal varieties of Dutch (the vernacular and dialects). After all, the playground is not the place where children spontaneously use academic language to converse with each other, and the playground does not distinguish between children speaking minority languages and children (and teachers!) speaking Dutch: they all have the same urge to use their own vernacular. In this perspective banning home languages outside the classroom is far from the best way of approaching things.

Schools also use pedagogical arguments to defend their Dutch-only policy. By encouraging the use of Dutch for all communicative purposes, schools hope to discourage the negative use of home languages (name-calling, bullying, social exclusion, forming of cliques, secret language, copying notes). One of the underlying justifications for this approach refers to the fear of losing control over the classroom and the playground. Teachers fear that children who are using their native language will get up to mischief or talk about this and that 
instead of working on their assignments. When a teacher does not understand what his students are saying, he will find it a lot more difficult to intervene appropriately.

There is however a difference between positively encouraging the use of Dutch at school and in class and entirely banning home languages. Experience shows that schools with a student body characterised by a broad variety of home languages do not need to encourage the use of Dutch; students spontaneously use Dutch as their conversational lingua franca. Prohibitive rules about the use of home languages do not seem to improve the use of Dutch either. They do however stigmatise the home languages and linguistic varieties of the students and are difficult to put into practice. Controlling the languages used in the playground or the refectory is a near-impossible task; it is simply impossible to ban the use of home languages entirely, even when schools adopt a policy of imposing penalties (which is impossible for teachers to uphold). Schools may opt for a compromise: allowing the use of home languages during recreational time and demanding the use of Dutch in the classroom. When working with toddlers, strict rules about language use are difficult to maintain. Nursery school teachers often need to use the home language of children who to begin with do not understand or speak Dutch. To forbid toddlers to speak their home language is no more realistic than enforcing strict linguistic rules (how would you ever explain it to them?), and it is likely to have a negative impact on their wellbeing.

\section{Responding to linguistic diversity at school, strategy 2: language awareness raising}

The concept of language awareness presents schools with another way of responding to linguistic diversity (Devlieger et al., 2011)). Interaction between students themselves and between students and teachers remains an important factor in the creation and moulding of attitudes and opinions about language, non-native speakers and multilingualism (Rampton, 1996). The arguments in favour of introducing language awareness in the classroom are 
primarily social-emotional and social-cultural: to make students receptive to linguistic diversity and to create a positive attitude towards all languages. Using this approach, schools try to stimulate students to open their mind to foreign languages and to motivate them to learn these languages. At the same time language awareness encourages the exchange of explicit knowledge and experience of when and how to use different languages.

Language awareness raising can be used for all foreign languages but it seems logical to focus on the home languages and linguistic varieties already present in the classroom (for example, when singing songs, counting, reciting the days of the week in different languages, language portfolio). A positive attitude towards linguistic diversity may contribute to a better understanding between children in the classroom and elsewhere at school (Genesee \& Gándara, 1999; Wright \& Tropp, 2005). It also contributes to the wellbeing and the development of the identity of non-native pupils. After all, this approach encourages these children to express their ideas, opinions and feelings in their own language. The attention paid to their native language increases its status, and because these children become experts in their mother tongue, their self-esteem increases, and with it, indirectly, their motivation to learn and their school results. At the same time it is important to acknowledge that the 'language awareness' approach is opportunistic in the sense that teachers can only exploit the linguistic resources that pupils bring with them to the classroom, and these are infinitely variable.

The same principles can be applied to parents as well as children. Language awareness raising may be an important way of increasing their involvement (Hélot \& Young, 2005): by considering them experts in their native language, just as their children are, schools acknowledge them and are likely to increase their self-confidence in their communication with members of the school team. In the same way parents can be encouraged to use their native language to help their children with their homework, which contradicts the common 
argument that they absolutely must master Dutch in order to help their children with their schoolwork.

To introduce language awareness into the school and classroom a realistic view of language and its use in an educational context is absolutely necessary. Language is still too often considered to be a linguistic system that should be reduced to an abstract, uniform standard.

In this approach multilingualism refers to 'multiple monolingualism': the level of competence one has in separate, independent languages (Blommaert \& Van Avermaet, 2008). Sociolinguists advocate a more subtle view of multilingualism as a reality in each and every one of us. Even when comparing individuals who speak the 'same' language, we find different linguistic varieties and spontaneous linguistic variation (Blommaert \& Van Avermaet, 2008; Van den Branden \& Verhelest, 2009). Hence, language is synonymous with multilingualism. Learning languages is a matter of expanding a multilingual repertoire of different genres, styles, registers and linguistic tools (for example: a spoken variant of the standard language, a spoken dialect, a sophisticated professional jargon, everyday jargon, writing, reading). No one can perfectly master all these different aspects of language and use them actively; no one can master a language entirely, not even their mother tongue. Multilingualism is a motley crew of different, unequally divided competences. Every aspect of language is specifically functional: mastering something in one domain doesn't guarantee success in another domain (for example: speaking English fluently doesn't mean you can write it fluently). In conclusion: outside school all students grow up in a multilingual environment; environments differ only according to the level of complexity and multiplicity. When it comes to immigrant children who speak a non-native language, it is clear that the environment they grow up in is characterised by a higher level of complexity and multiplicity. 


\section{Exploiting linguistic diversity at school, strategy 3: functional multilingual learning}

Between language awareness raising and multilingual education there are still a multitude of opportunities waiting to be discovered that we group together under the banner of 'functional multilingual learning'. This entails that schools use the multilingual repertoires of children and adolescents to ring the changes on knowledge acquisition. Pupils' home languages and language varieties can be seen as didactic capital that is deliberately exploited to foster personal development and increase their chances of educational success. The first language may serve as a stepping stone to the acquisition of the second language and the learning of new content.

The teacher encourages students to help each other in the execution of a task (for example: explaining to a new student with limited knowledge of Dutch what to do) or in the preparation of group work. This approach demands a certain working method: the teaching environment should allow students to interact on a regular basis and should not be entirely teacher-directed. During such intensive interactive moments the linguistic skills of the students help to solve a mathematical problem or to execute a task in physics. We use an example from a physics class to clarify what we mean: levers. The class is divided into groups of three and all groups are given some specific items, some Dutch texts with pictures and illustrations about levers, and a web page of 'Technopolis' with online experiments with levers. Students need to work out how the principle of levers actually works. One of the groups consists of three Turkish students. They are allowed to speak different languages while working on the experiments but need to read the texts in Dutch. If one of them doesn't understand the Dutch text or some parts of it, the other two are allowed to explain in Turkish; and if one of the students doesn't understand an instruction given by the Technopolis website, the others are allowed to clarify the instruction in Dutch. When the teacher joins this 
particular group he can give the students tips to get back on track if they should need them or give feedback/'feed forward' on how they have performed the task so far. In this way the teacher can assess whether the teaching process, which has taken place in a multilingual context, went well. Nine out of ten teachers will use Dutch as the language of instruction. This approach has several advantages: first the teacher reinforces the insights the students gained about how a lever works and offer adjustments where necessary. When student A explains something to student B in Turkish and the teacher paraphrases this in Dutch, the topics which are acquired in Turkish will reinforce the acquisition of certain concepts and insights about levers in Dutch. This is the core of functional multilingual learning; the insights about levers are gained using different linguistic pathways and academic language skills in Turkish and Dutch are both reinforced. Finally we wish to draw attention to the fact that in everyday life a fine line separates language awareness and the functional use of different languages; especially in kindergarten one approach merges imperceptibly with the other.

Scientific research into the functional applicability of home languages in the classroom is quite recent but shows promising results. Various studies in different countries conclude that when schools acknowledge and use the multilingual repertories of the students, they present them with better chances of educational success (for example: Jaffe, 2003; Moodley, 2007; Moschkovich, 2002; Olivares \& Lemberger, 2002; Olmedo, 2003; Peterson \& Heywood, 2007; Martin-Jones \& Saxena, 2001; Verhelst \& Verheyden, 2003).

An important advantage of this approach lies in the fact that the didactic use of home languages can be introduced into existing courses as a leitmotif. There is no need to alter the curriculum and adapt it to a multilingual approach. What is more, it is not necessary for teachers to know every single home language themselves. The most important aspect of the discussion is the recognition of linguistic diversity at school as an added value rather than a 
'problem' or 'deficit'. Linguistic diversity should be used to a maximum to create the best learning opportunities for all children.

\section{To conclude}

It is important to recognise that besides the school repertoire that children need to acquire, they also bring several additional repertoires to school (in Flanders another variety of Dutch, Berber, French, Arabic, Turkish, Polish, and so on). If we fail to recognise this diversity as an opportunity for learning and promoting equal opportunities, and consider only one repertoire as the exclusive norm for learning, that repertoire will be assigned a higher value than the others because it is accidentally used more frequently in certain social circles and less in others. If schools advocate the exclusive use of this repertoire, children living in social circles using this repertoire will have a huge head start. And, if schools fail to include the other repertoires as didactic support for the learning process, children using these repertoires will have a lot of catching up to do before they even start their educational career. In this chapter we have explored the possibilities of exploiting the linguistic diversity in the educational system as an asset for learning, based on the adoption of three strategies: a constructive language policy, linguistic sensitisation, and functional multilingual learning.

\section{References}

Archibald, J., Roy, S., Harmel, S., Jesney, K., Dewey, E., Moisik, S. \& Lessard, P. (2004) A review of the literature on second language learning. Prepared by the Language Research Centre (LRC) of the University of Calgary. Alberta: Alberta Learning. Adesope, O.O., Lavin, T., Thompson, T. and Ungerleider, C. (2010) A sytematic review and meta-analysis of the cognitive correlates of bilingualism. Review of Educational Research 80, 207-245. 
Agirdag, O. (2010) Exploring bilingualism in a monolingual school system: Insights from Turkish and native students from Belgian schools. British Journal of Sociology of Education 3, 307-321.

August, D. and Shanahan, T. (eds) (2006) Developing Literacy in Second-Language Learners: Report of the National Literacy Panel on Language-Minority Children and Youth. Mahwah, NJ: Lawrence Erlbaum.

Baker, C. (2006) Foundations of Bilingual Education and Bilingualism (fourth edition). Clevedon: Multilingual Matters.

Blommaert, J. and Van Avermaet, P. (2008) Taal, onderwijs en de samenleving. De kloof tussen beleid en realiteit. Berchem: Epo.

Byram, M. and Leman, J. (eds) (1990) Bicultural and Trilingual Education. Clevedon: Multilingual Matters.

Cummins, J. (1979) Linguistic interdependence and the educational development of bilingual children. Review of Educational Research 49, 222-251.

Cummins, J. (2000) Language, Power and Pedagogy: Bilingual Children in the Crossfire. Clevedon: Multilingual Matters.

Delrue, K., Loobuyck, P., Pelleriaux, K., Sierens, S. and Van Houtte, M. (2006) Uit het verdomhoekje van het Vlaamse onderwijs: comprehensief secundair onderwijs, concentratiescholen en meertalig onderwijs. In S. Sierens, M. Van Houtte, P. Loobuyck, K. Delrue and K. Pelleriaux, K. (eds) Onderwijs onderweg in de immigratiesamenleving (pp. 191-214). Gent: Academia Press.

Devlieger, M., Frijns, C. and Sierens, S. (2011) Wetenschappelijk rapport over talensensibilisering in de Vlaamse onderwijscontext: Literatuurstudie praktijkgericht onderwijsonderzoek in opdracht van de Vlaamse OnderwijsRaad. Brussels: Flemish Education Council. 
Driessen, G. (2005) From cure to curse: The rise and fall of bilingual education programs in the Netherlands. In J. Söhn (ed.) The Effectiveness of Bilingual School Programs for Immigrant Children (pp. 77-107). Berlin: WZB/AKI.

Francis, D. J., Lesaux, N., \& August, D. (2006). Language of instruction. In D. August \& T. Shanahan (Eds.), Developing literacy in second-language learners: Report of the National Literacy Panel on language-minority children and youth (pp. 365-413). Mahwah, NJ: Erlbaum.

García, O. (2009) Bilingual Education in the 21st Century: A Global Perspective. Oxford: Wiley-Blackwell.

Genesee, F. and Gándara, P. (1999) Bilingual education programs: A cross-national perspective. Journal of Social Issues 55, 665-685.

Genesee, F., Lindholm-Leary, K., Saunders, W. and Christian, D. (eds) (2006) Educating English Language Learners: A Synthesis of Research Evidence. Cambridge: Cambridge University Press.

Gogolin, I. (2005) Bilingual education - The German experience and debate. In J. Söhn (ed.) The Effectiveness of Bilingual School Programs for Immigrant Children (pp. 133-143). Berlin: WZB/AKI.

Hamers, J.F. and Blanc, M.H.A. (2000) Bilinguality and Bilingualism (second edition). Cambridge: Cambridge University Press.

Hélot, C. and Young, A. (2005) The notion of diversity in language education: Policy and practice at primary level in France. Language, Culture and Curriculum 18, 242-257. Huguet, A., Vila, I. and Llurda, A. (2000) Minority language education in unbalanced bilingual situations: A case for the linguistic interdependence hypothesis. Journal of Psycholinguistic Research 29, 313-333.

Jaffe, A. (2003) Talk around text: Literacy practices, cultural identity and authority in a 
Corsican bilingual classroom. International Journal of Bilingual Education and Bilingualism 6, 202-220.

Jaspers, J. (2005) Linguistic sabotage in a context of monolingualism and standardization. Language and Communication 25, 279-297.

Köbben, A.J.F. (2003) Het partiële gelijk: pro en contra het 'Onderwijs in de Eigen taal'. In Het gevecht met de engel (pp. 122-134). Amsterdam: Mets \& Schilt.

Laevers, F., Van den Branden, K. and Verlot, M. (2004) Beter, breder en met meer kleur. Onderwijs voor kwetsbare leerlingen in Vlaanderen. Een terugblik en suggesties voor de toekomst. Leuven: Steunpunt Gelijke Onderwijskansen.

Lambert, W.E. (1974) Culture and language as factors in learning and education. In F.E. Aboud and R.E. Meade (eds) Bilingualism: Psychological, Social and Educational Implications (pp. 91-127). Bellingham: Western Washington State College.

Lazaruk, W. (2007) Linguistic, academic and cognitive benefits of French immersion. The Canadian Modern Language Review 63, 605-628.

Leung, C. (2005) Language and Content in Bilingual Education. Linguistics and Education $16,238-252$.

Martin-Jones, M. and Saxena, M. (2001) Turn-taking and the positioning of bilingual participants in classroom discoruse: Insights from primary schools in Britain. In M. Heller \& M. Martin-Jones (eds) Voices of Authority and Linguistic Difference (pp. 117138). London: Ablex.

Moodley, V. (2007) Codeswitching in the multilingual English first language classroom. International Journal of Bilingual Education and Bilingualism 10, 707-722.

Moschkovich, J. (2002) A situated and sociocultural perspective on bilingual mathematics learners. Mathematical Thinking and Learning 4, 189-212.

Olivares, R.A. and Lemberger, N. (2002) Identifying and applying the communicative and the 
constructivist approaches to facilitate transfer of knowledge in the bilingual classroom. International Journal of Bilingual Education and Bilingualism 5, 72-83.

Olmedo, I.M. (2003) Language mediation among emergent bilingual children. Linguistics and Education 14, 143-162.

Padilla, A.M. (1991) English only vs. bilingual education: Ensuring a language-competent society. Journal of Education 173, 38-51.

Peterson, S.S. and Heywood, D. (2007) Contributions of families' linguistic, social, and cultural capital to minority language children's literacy: Parents', teachers', and principals' perspectives. The Canadian Modern Language Review 63, 517-538.

Rampton, B. (1996) Crossing: Language and Ethnicity among Adolescents. London: Longman.

Rolstad, K., Mahoney, K. and Glass, G.V. (2005) The big picture: A meta-analysis of program effectiveness research on English language learners. Education Policy 19, $572-594$.

Slavin, R.E. and Cheung, A. (2005) A synthesis of research on language of reading: Instruction for English language learners. Review of Educational Research 75, 247-284.

Slavin, R.E., Madden, N., Calderón, M., Chamberlain, A. and Hennessy, M. (2011) Reading and language outcomes of a multiyear randomized evaluation of transitional bilingual education. Educational Evaluation and Policy Analysis 33, 47-58.

Söhn, J. (2005) Zweisprachiger Schulunterricht für Migrantenkinder: Ergebnisse der Evaluationsforschung zu seinen Auswirkungen auf Zweitspracherwerb und Schulerfolg. Berlin: WZB/AKI.

Stad Gent (2007) Basistekst 'Thuistaal in onderwijs'. Gent: Stad Gent, DOOSG, Pedagogische Begeleidingsdienst. 
Thomas, W.P. and Collier, V.P. (2002) A National Study of School Effectiveness for Language Minority Students' Long-term Academic Achievement. Santa Cruz, CA: Center for Research on Education, Diversity and Excellence, University of CaliforniaSanta Cruz.

Van den Branden, K. and Verhelst, M. (2008) Naar een volwaardig talenbeleid. Omgaan met meertaligheid in het Vlaams onderwijs. TORB (Tijdschrift voor Onderwijsrecht en Onderwijsbeleid) 2007-2008, 315-332.

Verhelst, M. and Verheyden, L. (2003) Eindrapport Pilootproject Circus Kiekeboe. Leuven: K.U. Leuven, Centrum voor Taal \& Migratie.

Verlot, M. (2001) Werken aan integratie. Het minderheden- en het onderwijsbeleid in de Franse en Vlaamse Gemeenschap van België (1988-1998). Leuven: Acco.

Verlot, M., Delrue, K., Extra, G. and Yağmur, K. (2003) Meertaligheid in Brussel. De status van allochtone talen thuis en op school. Amsterdam: European Cultural Foundation.

Wright, S.C. and Tropp, L.R. (2005) Language and intergroup contact: Investigating the impact of bilingual instruction on children's intergroup attitudes. Group Processes and Intergroup Relations 8, 309-328.

http://www.rethinkingbelgium.eu/rebel-initiative-files/events/sixth-public-event-languagesschool-curriculum-and-school-registration-admission-policies/Mettewie-Housen.pdf 